\title{
The Implementation of Russian Federation's Coercive Diplomacy towards Ukraine in the New Great Game Context over Gas Pipeline Dispute (2006 -2009)
}

\author{
Anak Agung Banyu Perwita \& Nurhayati Pakpahan
}

President University

\begin{abstract}
The worsening of technical and safety condition of the pipeline infrastructure in Ukraine due to economic crisis following the end of the Cold War had driven Russia to provide compensation to Ukraine through applying subsidy on its gas price and paying the Ukrainian gas imports as long as Ukraine keep its promise to pay back the country's debt until 2005. However, since Ukraine's integration with the United States and its Western Allies by asking to become part of North Atlantic Treaty Organization and European Union state members, it refused to pay its high gas debts to Russia. This situation made Russia feels threatened towards its national security where there will be a possibility to the fall of Russian political influence in Ukraine. In 2006, Russia decided to implement its coercive diplomacy actions towards Ukraine through politicizing its gas sector.
\end{abstract}

Key words: Coercive diplomacy, energy security, territorial dispute, geopolitial importance.

Buruknya kondisi teknis dan keamanan infrastruktur pipa gas Ukraina akibat krisis ekonomi paska berakhirnya Perang Dingin mendorong Rusia memberikan kompensasi terhadap Ukraina melalui pemberian subsidi harga gas dan tanggungan biaya impor gas, selama Ukraina berjanji membayar hutang-hutang gas berdasarkan waktu yang dijanjikan Rusia hingga tahun 2005. Namun, sejak Ukraina berintegrasi dengan Amerika Serikat, NATO dan Uni Eropa (EU), Ukraina menolak melunasi hutang gas kepada Rusia. Hal ini mengancam keamanan nasional Rusia dari kemungkinan hilangnya pengaruh politik Rusia di Ukraina. Pada tahun 2006 Rusia memutuskan menjalankan strategi diplomasi koersifnya terhadap Ukraina melalui praktek politisasi dalam sektor gasnya.

Kata-kata kunci: diplomasi koersif, keamanan energi, sengketa wilayah, kepentingan geopolik 
The concern about Energy Security has been always becoming the most important and heated discussion in international politics even until today. Although the issue that related to this aspect was always happening from time to time, flashing across our media electronic such as in television, internet and newspaper columns, it is still really difficult for some scholars to find and explain how the concept of energy security will be kept in line with the reality of our modern life. This considered as the evidence that energy security is categorized as one of the ambiguous, abstract and complex term in the world politics, which its characters always change overtime (Yergin 2011).

Barton defines energy security as "a condition in which nation and all, or most, of its citizens and businesses have access to sufficient energy resources at reasonable prices for the foreseeable future, free from risk of major disruption or service." (Barton, 2004). There are some important elements that could be elaborated from this definition. The first one is related to the sufficiency of resources. It means that the availability of physical energy resources is not only coming from fossil fuels (e.g. oil, gas and coal), but also could be from non-fossil ones (e.g. renewable energy resources or nuclear energy). With plurality of resources, it is possible for every state to implement what it calls as the diversification of energy resources.

The second element is referring to the price that should have to be "reasonable". It means that with the character of energy security that always dynamic, there will be a time where change of energy price and scarcity of energy supplies can happen in the future and eventually will bring negative impact towards the rate of society's prosperity within certain countries that regularly always use lot of energy resources. The last element refers to the risk of major disruption in public services of a country if energy security of particular state is being threatened, where its society is considering energy itself as their primary needs due to the scarcity of energy resources. On the next section, there will be a further research of Russian government roles in energy security in Ukraine, which back then focused only in economic and business matters changed into a form Russia's politicization of energy supply in Ukraine as part of its coercive diplomacy actions. After introducing this issue briefly, it will be elaborated more on case study section in order to apply independent variable within the central issue in the next section.

\section{Coercive Diplomacy and The New Great Game Theory}

For analyzing and explaining further about the core problem within this case, it would be started with understanding a significant theory and certain concepts as interconnection of the theory itself. The most 
significant theory on explaining this case would be coming from Coercive Diplomacy and The New Great Game. However, before elaborating this theory, we should have to know first the basic term of securitization of energy issues which considers as a crucial point within the study of International Relations.

In terms of securitization of energy issues, the main problem of the securitization process itself is coming from finding the exact securitizing actor who represents the existential threat within energy issues. It implies hat the relevant securitizing actors in energy security are mostly depending on who is speaking about the related issues first (Roberts 2004). As for existential threat that coming from energy security, it could be defined based on a perspective of Paul Roberts: "A failure of energy security means that the momentum of industrialization and modernity grinds to a halt, and survival itself become far less certain." (Roberts 2004)

This means that when those of securitizing actors in energy security are facing certain challenges such as lacking of infrastructures on finding energy resources in certain areas or losing the capability on maintaining their energy supplies for public services, those challenges are considered as their threats. That is why they need to take out a decision on solving those threats.

Then there is an understanding of coercive diplomacy conception. Coercive diplomacy is a diplomatic strategy aiming to achieve political objectives within one state and fostering its national interest without waging a war. This is a strategy on using the threat of force instead of applying full - scale of military actions in order to make the state's target complying with its demand. This political-diplomatic strategy is also being enforced for persuading its target to back down and stopping an action already conducted which considered could bring the conflict into a state of war. (Schettino 2009)

However, as the antithesis of Ilario Schettino statement above, in my opinion Coercive Diplomacy is obviously considered as part of diplomatic and defensive strategy. We can see on the application of the strategy itself that in diplomacy part, coercer state applies its demands towards particular state (that is considered as a target state) through conducting a meeting or making several contracts and agreements which containing about those demands as a form of both countries' negotiation. In defensive part, while taking out several demands towards the targeted state, coercer state on the same time employing threats (whether those threats are being limited or not) in the form of punishments or sanctions for making this target state to stopping its actions that totally against coercer state's preferences or undo the action that already conducted by target state which already gave benefits on its 
coercer one without putting up any kind of non-compliance or resistance.

That is why even though in one time the coercer state will arrange agreements or contracts as part of its negotiation with its targeted state, after that the coercer state will giving particular threats towards its target as part of its use of force (conducting violation but does not mean to apply a full scale of military actions) if its target giving countermeasures back until this target state comply with what coercer state prefers for.

\section{Picture 1. Matrix of Coercive Diplomacy Conception}

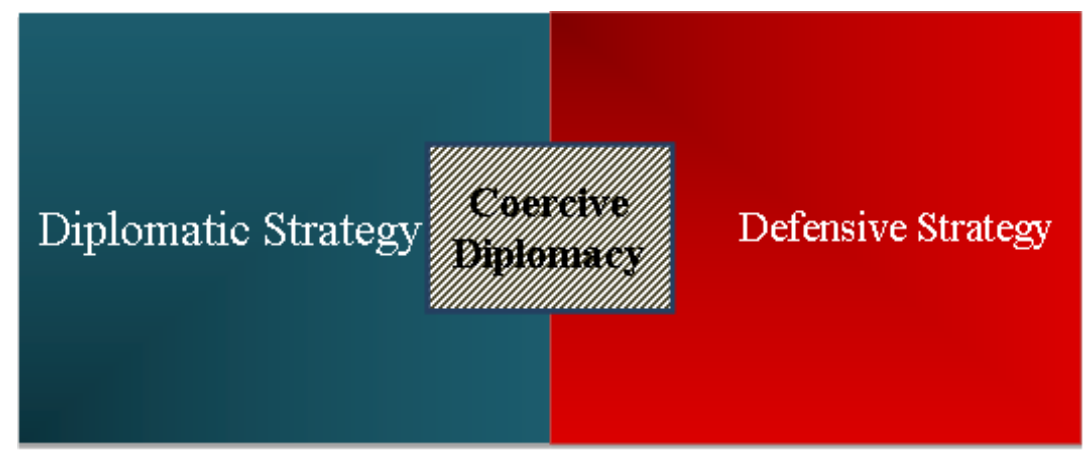

There are two (2) types of extreme "variants" or methods on applying coercive diplomatic strategy (in Coercive Diplomacy: Integral Element of Diplomatic Negotiations, 2012) those are (1) Try-and-see approach and (2) Ultimatum approach (consists of 3 components, they are demand, threat and time pressure)

The use of these two variants could shift from one into another by policymakers depends on a state's implementation to each step it has taken. As for the first approach, it will be used when a coercer state takes one threatening step in one moment, waiting for its target's reaction before imposing additional threats without setting time limitation. However, for the second one, it consists of three processes, such as a demand, a threat and time pressure. (Jacobesen, $\mathrm{tt}$ )

Thus, even though the coercive diplomacy is categorized as a diplomatic strategy by using threat of force, the fact is that it also has the goal for preventing a war and to achieve a global peace.

In terms of The New Great Game context, it is considered by Duarter in 2012 as a competition on the importance of geopolitics of energy in some of Eurasia countries, whose the main players for this game have been 
added with the involvement of non-state actors and resulted in an establishment of new natural gas pipeline, LNG tanker route, oil consortium, and a new signed agreement (Duarte, 2012). Those states which competing each other within the new great game context are mostly coming from United States and its NATO allies against Russia along with its state monopoly companies for gaining a new political hegemony in Eurasia region, particularly in Commontwealth of Independent States' (CIS) space.

Based on the hierarchical level of analysis in terms of main players within the new game as what Boris Rumer has stated, the major powers which are involving within the game could be considered as first level of analysis, while for secondary ones are coming from those Eurasian countries (mostly from Central Asia, Slavic Union and Caucasus region) since they are also having their own ambition and interest in a regional level. As from non-state actors, they are being considered as parts of the second level of analysis which then divided into the supra - State (e.g. NATO, UN, OSCE, etc) and the infra - State categories (e.g. NGOs, MNCs, terrorist groups, criminal organizations, etc) (Boris Rumer, 2005).

Picture 2. Hierarchy of The Main Players in A Context of New Great Game Theory

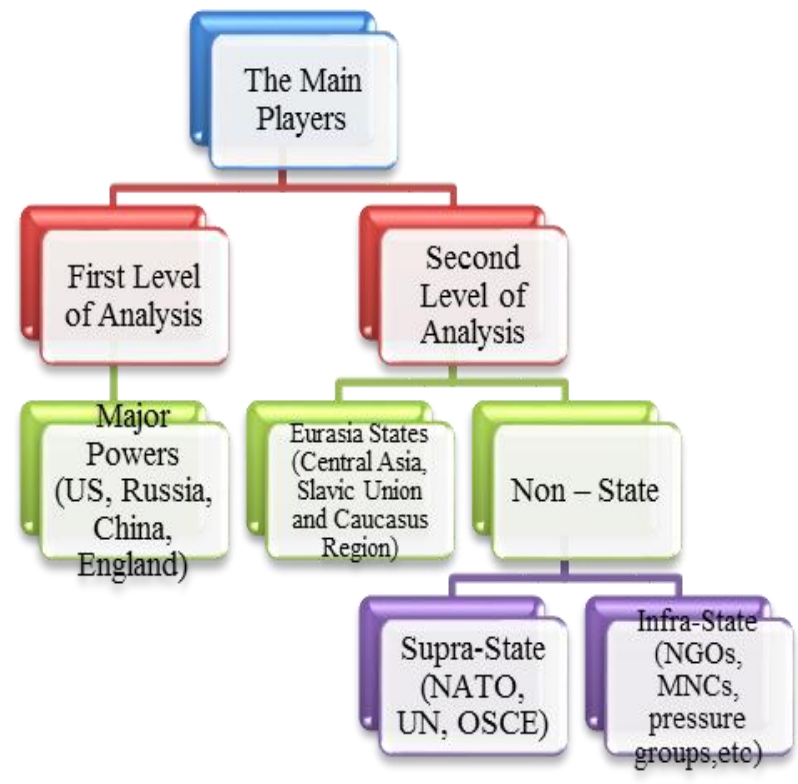




\section{Russia's Coercive Diplomacy Implementation towards Ukraine in Responding Orange Revolution}

The cause of why gas conflict between Russia and Ukraine happened in the early 2006 can be seen chronologically based on the biggest event that happened 11 years ago in Ukraine which still coming into the mind of people in several states of post-Soviet space and the West countries. After mass protests happened between Ukrainian society who were supporting Yanukovych (pro-Russia government) and Yushchenko (proWestern government), the third round of Ukraine's presidential election in 2004 resulted with people elected Viktor Yushchenko as the country's first president where they considered him could enlighten the dark age of Ukraine's state system under authorization of Russia as the dominant country in post-Soviet space.

The Ukrainian people also considered this election as the first time where the real democratic system and transparency become visible in more than several years of Ukrainian history. The mass protests in Ukraine eventually had led into the existence of reformist coalition power under Yushchenko which called as Orange Revolution. Unfortunately, the result of choosing Yushchenko as the President of Ukraine at that time started to worry Russia, since it means that the opportunity to implement its political influence as a major power country in Eurasia region, particularly in post-Soviet space would be disappeared Tugce 2013).

The revolution in Ukraine obviously brought a threat for Russia's national interests along with its national identity inside Ukrainian country. Not only that, the biggest threat that Russian government faced at that time was related to the effect of revolution itself, where eventually the change of political system under Russia's government structure umbrella could trigger several countries in CIS space to conduct "color revolution" as well, such as like "Rose Revolution" that happened in Georgia in 2003 or "Tulip Revolution" in Kyrgyzstan in 2015. (Herd 2011).

Later, on December 31 in 2005, Russian President Vladimir Putin gave statements on the national television that he would give the last chance for Ukraine until midnight to accept his offers by ordering Gazprom, as the biggest gas national company that controlled by Russian Government to keep selling its subsidized gas to the country until in the end of March, as long as Ukraine agreed to pay it in European market level prices started from April and beyond. However, Yushchenko refused the Russian offer by saying that Putin's offer considered as "economic pressure". Thus, started on January 1 in 2006, Russia conducted a total shutdown of its natural gas supplies for Ukraine and Western European countries by reducing the flow of its gas initially from 
20\% into $0 \%$ for the next four days (until 4 January 2006) (Jonathan 2006).During the crisis, Gazprom accused Ukraine that the declining of gas supplies to its customers was coming from the country's gas siphoned off 100 million cubic meters that should have distributed for its EU costumers; while from Ukrainian side, the decline of gas volumes to EU was --no other than due to-- Russia's pressure towards Ukraine for still not agreeing to pay the supplies with high prices.

Aside from that, in terms of Ukraine's embezzle action towards Russian gas supplies, based on both countries' annual contracts it was already stated that Ukraine has its rights for taking $15 \%$ of Russia's gas which is crossing Ukraine's territory for delivering it to European countries as barter transit payment from Russia for being allowed to use Ukraine's GTS (Jonathan 2006). But Russia denied Ukraine's statements and kept perceiving Ukraine as a gas "theft". In order to solve the case, in January 2 Gazprom took its responsibility by pumping additional 95 million of cubic meters everyday to EU countries as a part of compensation on the gas that Ukraine had taken (Jonathan 2006).

Since the long - term gas dispute between both countries would be difficult to be solved, Ukraine then tried to diversify its gas stocks from another gas - producer country. Thus, during the year of the dispute, Ukraine would fulfill the country's gas needs by importing 4obn cubic meters of gas from Turkmenistan. that The gas was distributed throughout pipelines crossing Russia as what (it) had been dealt on with Turkmen president Saparmurat Niyazov on December 23 in 2005 at price around $\$ 50$ - $\$ 60$. However, with Russia's gas policy which also wanted to increase its own purchases towards Turkmen's gas by readying (willing) to pay in a higher price (around \$65) based on signed agreement between both parties on December 29.

It made the Turkmenistan government to announce Ukraine that the contract between both countries was no longer valid due to Turkmenistan's distrust towards Ukraine which still could not pay its gas debts for the country (Simon 2007). It was obvious that Russia during that time tried to improve its efforts on reducing and preventing --the gas supply deliveries from-- other countries come to Ukraine, which make the possibility for Ukraine to gain large amount of gas volumes aside from Russia will be smaller than what it had expected.

However, even though the agreement that had been made by Gazprom, RosUkrEnergo and Naftogaz Ukrainy (as two biggest national gas companies controlled by Ukrainian Government) to solve gas dispute between these two countries stated that Ukraine would gain its gas demands from both Central Asian countries and Russia, in fact on two days after the deal has been agreed it was confirmed that in 2006 Ukraine would not receive any of gas imports from Russia. 
Consequently, (which means that $56 \mathrm{bcm}$ of Ukraine's gas imports were mostly coming from Central Asia only).

It could be seen on October 2006 Ukraine had applying its remarks by announcing that the country had signed contracts with Uzbekistan, Kazakhstan and Turkmenistan to gain $58 \mathrm{bcm}$ of gas from these countries, and with this reason, Ukraine would not purchase its gas supplies from Russia anymore started in 2007 (states by Yuriy Boiko, the Ukraine's fuel and energy minister). But it could not be avoided that in the end the process of gas imports from Central Asia countries to Ukraine should have to involve Russian presence, which controlled by Gazprom. Thus, starting on December 4 in 2007, Gazprom chairman along with fuel and energy minister of Ukraine eventually had made an agreement to accept a new gas import price with a price around $\$ 179.5$ which would be set up in 2008 in Russian and Ukrainian territorial boundaries.

Based on the case of Russia and Ukraine hostile bilateral relations during Gas Dispute in 2006 until 2009, Russia at that time used "Try and See" method by taking out several demands towards Ukraine such as asking for pay Ukrainian gas debts along with paying its gas imports in normal price (based on European gas market levels which was measured around US\$260-US\$230). Aside from that, Russia also asked for Ukraine to take responsibility over disappearance of gas supplies which supposed to be exported to Western European countries through applying limited threat which stating that Russia would reduce its gas supplies to Ukraine into 20\%. However, after that Ukraine did a counterreaction towards Russia by giving statement that it would not responsible on the disappearance of Russia's gas supply, rejected to sign the contract that containing about the change of the country's payment on Russian gas exports with Gazprom and instead strengthening its ties with the West (particularly towards NATO and EU) as part of Ukraine's resistance to comply with Russia's demands. After that, Russia then took out a further step by applying Ultimatum method through taking out specific demands and put all of those demands from standard ones (e.g. paying debts) into intermediate level (controlling over part of target state's territory) with time limitation for target state to reply on all of those demands. On this case, Russia then took out its specified demands from asking to pay Ukraine's gas imports in normal level into a demand for handling over the control of Russia's Black Sea Fleet in Sevastopol Port and its city in Crimea to Russia, and Ukraine was having its chance to reply on the demands until around midnight on December 31, 2005.

But still, Ukraine, particularly from Viktor Yushchenko, rejected the demands stated by Vladimir Putin by saying that Russia conducted "economic pressure" towards Ukraine, given economic downturn that still happened at that time inside Ukraine. On the day after tomorrow, 
Russia then started to apply its coercive measures which considered as the form of Russia's punishments through cutting its gas supplies into o\% towards Ukraine and EU countries from January 1 until January 4th in 2006, making sure Russia always get involve on gas export activities that coming from Central Asia countries to Ukraine and conducting annexation over Crimea in order to protect and support its compatriots within the disputed areas due to the Ukrainian stance for keep rejecting its agreement for extending Russia's BSF presence in Sevastopol and Crimea, where during this period also both countries still have major confrontation from social ethnic and political groups upon the sovereignty of Sevastopol city and Crimea. The diagram below shows about the process of Russia's coercive diplomacy implementation towards Ukraine.

\section{Picture 3. Try-and-See Approach of Russia's Coercive Diplomacy Implementation}

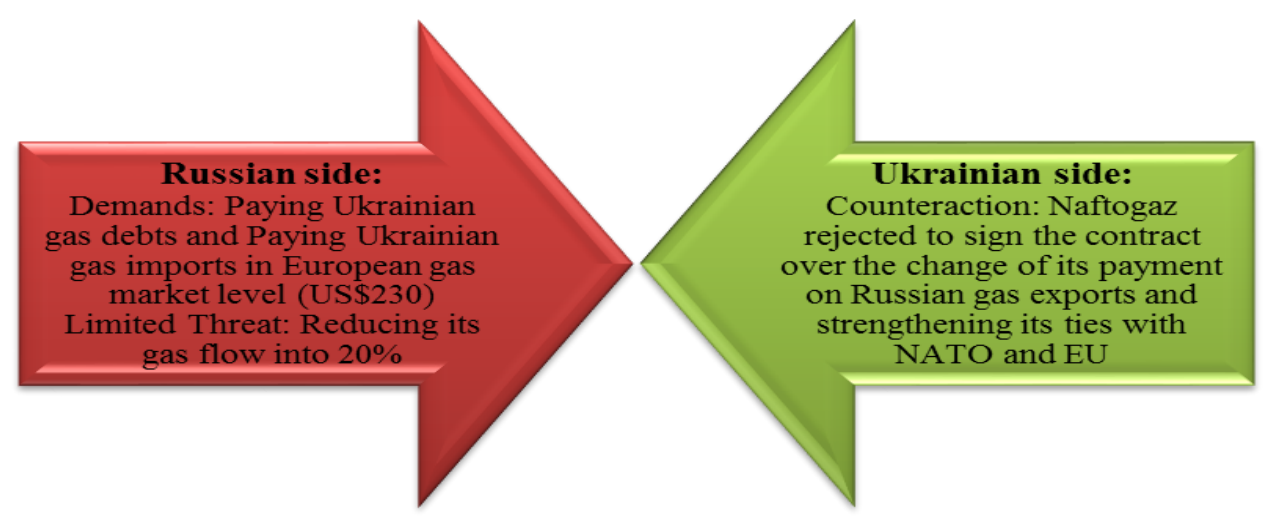

\section{Picture 4. Ultimatum Approach of Russia's Coercive Diplomacy Implementation}

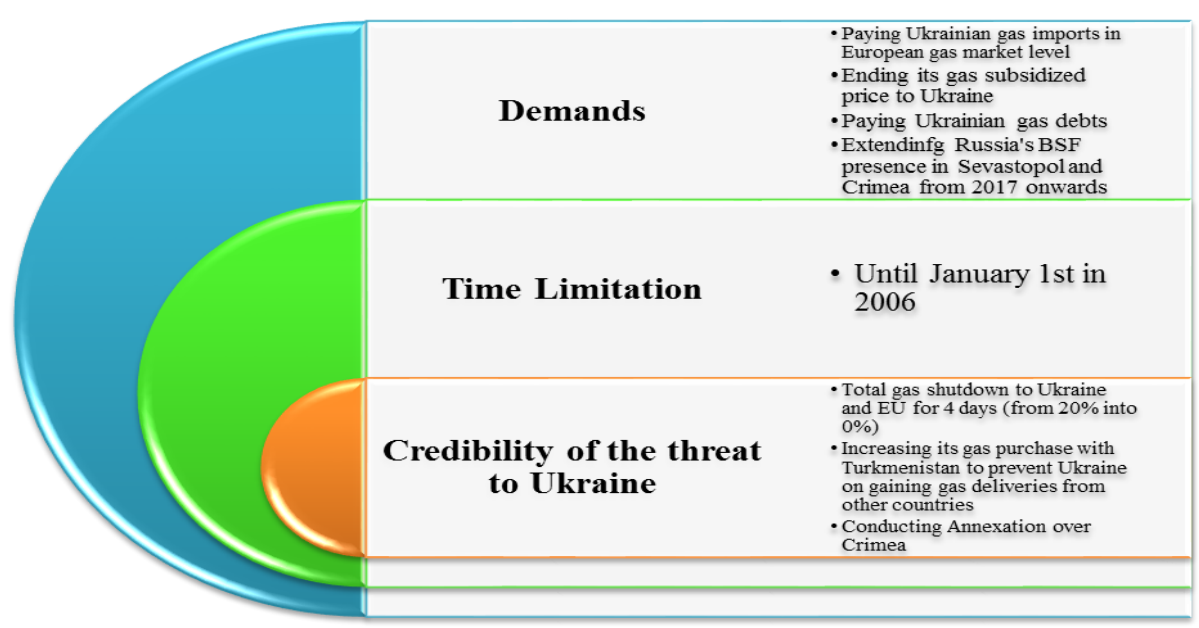




\section{Conclusion}

After explaining about the component of Russia's implementation on its coercive diplomacy actions towards Ukraine, it can be explained that asymmetrical condition was happened between both countries during that time. It means that even though Ukraine made its "counteractions" to Russia by keep improving its relations with the West, in fact there was no balance of power between Russia and Ukraine on this case, particularly in gas resources that included as the vital value for both countries. Theoretically, if asymmetrical situation is happened between state A and state B as state A's rival (when state A is conducting its coercive diplomacy actions towards state B as target state), it would be possible that bilateral relationship between state A and state B will be more complicated in the future, and even it will turn out into "the state of conflict/war" due to the failure of state A on stopping an action that already conducted by state B which against state A's preferences to achieve global peace. Thus, it will be possible that Russia and Ukraine will face an intense conflict escalation which eventually will turn into the state of war in continuing both countries' long-term dispute in gas sector.

\section{References}

\section{Books and Journals}

Allison, Graham and Blackwill, Robert D. 2011. Russia and U.S. National Interests: Why Should Americans Care? Washington, DC and Cambridge: Center for the National Interest and Belfer Center for Science and International Affairs

B, Barton, 2004. A Review of Energy Security. UK: Oxford University Press

Cooley, Alexander and Dubovyk, Volodymyr, 2008. Will Sevastopol Survive? The Triangular Politics of Russia's Naval Base in Crimea. PONARS Eurasia Policy Memo No. 47

George, Alexander, 1991. Forceful Persuasion: Coercive Diplomacy as an Alternative to War. Washington, DC: United States Institute of Peace Press

Gorenburg, Dmitry, 2008. The Russian Black Sea Fleet After The Georgia War. Harvard University: PONARS Eurasia Policy Memo No. 48

Kong Chyong, Chi, 2014. Why Europe Should Support Reform of the Ukrainian Gas Market - or Risk a Cut - Off. European Council on Foreign Relations (ecf.eu) 
Labuszewska, Anna, 2003. The resource wealth burden - oil and gas sectors in the former USSR. Warsaw: Centre for Eastern Studies

Mulalić, Muhidin and Karić, Mirsad, 2014. The Western Balkans Geopolitics and Russian Energy Politics. Epiphany: Journal of transdisciplinary studies

Pirani, Simon, 2007. Ukraine's Gas Sector. UK: Oxford Institute for Energy Studies

Varol, Tugce, 2013. The Russian Foreign Energy Policy. Republic of Macedonia: EGALITE

Yergin, Daniel, 2011. The Quest: Energy, Security, and the Remaking of the Modern World. New York: Penguin Group.

\section{Online Articles, News and Reports:}

DW.com. Russian Security Plan Prompts Fears Over Future Energy War[online]from www.dw.com/en/russian-security-plan-promptsfears-over-future-energy-wars/a-3938485[retrieved on November $15,2015]$

E-IR Info. Is Coercive Diplomacy a Viable Means to Achieve Political Objectives?[online]http://www.e-ir.info/2009/06/29/is-coercivediplomacy-a-viable-means-to-achieve-political-objectives/[retrieved on September 23, 2015]

Ecfr from EU. The Role of Russian Gas in Ukraine[online]. http://www.ecfr.eu/article/commentary_the_role_of_russian_gas_ in_ukraine248[retrieved on September 30, 2015]

Formal website of Russian MOFA. The Ministry of Foreign Affairs of the Russian Federation official site: Concept of the Foreign Policy of the Russian Federation [online]. www.archive.mid.ru/brp_4.nsf/o/76389FEC168189ED44257B2Eoo 39B16D[retrieved on October 23, 2015]

Jamestown.org. Russian Analysts Ponder Orange Revolution's Implications for Kremlin Dominance in CIS [online].http://www.jamestown.org/single/?no_cache=1\&tx_ttnews $\% 5 \mathrm{Btt} \_$news\%5D=27281\#.VhJIheyqqkp[retrieved on October 4, 2015]

The Guardian. Russia turns off supplies to Ukraine in payment row, and $E U$ feels the chill[online].http://www.theguardian.com/world/2006/jan/o2/russ ia.ukraine[retrieved on October 9, 2015]

Russia flexes its military muscle[online]. www.theguardian.com/commentisfree/2009/jan/04/russia[retrieve d on November 15, 2015]

UPI.com. Ukraine deploys ship for NATO operation[online\} www.upi.com/Top_News/Special/2008/11/17/Ukraine-deploys- 
ship-for-NATO-operation/72341226966792/[retrieved on Ocober 31, 2015]

Washington Post. Petro - aggression: How Russia's Oil Makes War More Likely [Online] https://www.washingtonpost.com/ news/monkey-cage/wp/2014/04/o1/petro-aggression-how-russiasoil-makes-war-more-likely/[Retrieved on November 15, 2015] 